\title{
Freshwater diversity in Svalbard; providing baseline data for ecosystems in change
}

\begin{abstract}
Bjørn Walseng ${ }^{1}$, Thomas Jensen ${ }^{1}$, Inta Dimante-Deimantovica ${ }^{1}$, Kirsten S.
\end{abstract} Christoffersen ${ }^{2}$, Mikhail Chertoprud ${ }^{3}$, Elena Chertoprud ${ }^{3}$, Anna Novichkova ${ }^{3}$ and Dag O. Hessen $^{4}$

${ }^{1}$ Bjørn Walseng, Thomas Jensen, Inta Dimante-Deimantovica, NINA, Gaustadalleen 21, 0349, Oslo, Norway (bjorn.walseng@nina.no)

${ }^{2}$ Kirsten S. Christoffersen, The University Centre in Svalbard, 9171, Longyearbyen, Norway (kchristoffersen@bio.ku.dk)

${ }^{3}$ Mikhail Chertoprud, Elena Chertoprud, Anna Novichkova, M. V. Lomonosov Moscow State University, Vorobyevy Gory, 119992, Moscow, Russia (horsax@yandex.ru) ${ }^{4}$ Dag O. Hessen, University of Oslo, Dept. Bioscience, Section for Aquatic Ecology and Toxicology, P.O. Box 1066 Blindern, N-0316 Oslo, Norway (d.o.hessen@mn.uio.no)

Keywords: Arctic - crustaceans - meiobenthos - macroinvertebrates - succession authenticated version is available online at: http://dx.doi.org/ 10.1007/s00300-018-2340-3. 


\section{Acknowledgment}

This study was a joint campaign among Norwegian and Russian researchers. Both

25

26

27
0 1 partners were involved in preparing the study design, as well as participating in meetings, fieldwork (2014 and 2015) and analyzing/reporting of collected material. We owe thanks to UNIS (the University Centre in Svalbard), NPI (the Norwegian Polar Institute), the Governor of Longyearbyen and all the people in Barentsburg and Pyramiden for their valuable support during fieldwork. Thanks also to Olga L. Makarova who identified mites. The study of ecology and taxonomy of Cyclopoida (Copepoda) was supported by the programme "Scientific bases for the creation of a national depository bank of living systems of the Russian Science Foundation [grant number 14-50-00029]”. The study of ecology and taxonomy of Harpacticoida (Copepoda) was supported by the Russian

34 Foundation for Basic Research [grant number 17-04-00337-a]. Further, this study was

supported by the Norwegian Institute for Nature Research (NINA) and the Research Council of Norway projects; "Effect of climate change and related stressors on fresh and brackish water ecosystems in Svalbard [227024]" and "The effect of nutrient input from migrating birds on the succession of freshwater communities of different age in Svalbard [246726]". 


\section{Abstract}

44 effects due to warming and an extended growing season, as well as an indirect effect

45 caused by increased bird activity and density (notably geese), strongly affect ponds and

46 lakes. Our study presents the hitherto most comprehensive data on invertebrate

47 freshwater diversity at Svalbard and had three main purposes: to provide a current

48 "baseline" of community composition, to compare current species distribution and

49 occurrence with older data to identify changes that have already occurred, and finally to

50 identify how diversity and community composition are related to the age of localities.

51 To address these aims we conducted a survey of freshwater invertebrates in 75 ponds and

52 lakes at Svalbard in August 2014 and 2015. We provide a full report of the species

53 inventory for zooplankton, benthos and meiofauna. We also provide data for species that

54 have likely colonized the sites over the past decades. Finally, our study also clearly

55 demonstrates a diversity gradient related to ecosystem age and/or parameters

56

57

58

59 


\section{Introduction}

Few places on the planet have witnessed a more dramatic climate change than the high Arctic, and this is expected to continue for the foreseeable future (IPCC 2013). The loss of sea ice, together with increasing air and water temperatures, has also caused major changes on terrestrial habitats such as of the Svalbard archipelago in the North Atlantic (Bhatt et al. 2010). Climatic recordings on the west-coast of the archipelago show a steady increase of approximately $2^{\circ} \mathrm{C}$ in air temperature over the past 30 years (Holm et al. 2012), with some truly extreme temperature records over the past few years. Extended growing seasons, the retreat of glaciers, thawing of permafrost, changes in hydrology and "greening" by increased vegetation cover are prominent effects in the Arctic (IPCC 2013; Xu et al. 2013). Also, numerous small water-bodies, ponds and many arctic lakes are impacted by direct warming, permafrost melt and increased fluxes of organic carbon and nutrients from the surrounding landscape (Quinlan et al. 2005; Smol et al. 2005; Smol and Douglas 2007; Rautio et al. 2011; Luoto et al. 2015). Also, faunal changes, notably birds, may serve a dual role by fertilizing and/or serving as vector for species migrations (van Geest et al. 2007; Hessen et al. 2017).

Research on the impacts of climate change in the Arctic has become a priority issue, and there is currently a wide range of studies on climate, environment and ecosystem issues. Extensive terrestrial monitoring programs have been conducted (e.g. Ims et al. 2014), and there are both regional and national monitoring programs of pollution covering high-arctic territories in Svalbard. Extensive efforts on research and data collection have been carried out on abiotic systems (atmosphere, meteorology, glaciers) and ecosystems (terrestrial and marine systems). There has been less effort devoted to freshwater ecosystems in the high Arctic, despite their strong vulnerability to climate change and other stressors (Smol et al. 2005; Smol and Douglas 2007; Christoffersen et al. 2008). Being closed entities (“aquatic islands”) with simple ecosystems, they also offer ideal monitoring units. The need for more efforts towards responses in freshwater ecosystems has also recently prompted the establishment of a Freshwater Expert Monitoring Group (Culp et al. 2012). To separate faunal changes from random variability, there is a strong demand not only for time series and monitoring but also for proper baseline data. authenticated version is available online at: http://dx.doi.org/ 10.1007/s00300-018-2340-3. 
Most of the freshwater sites in Svalbard are young, and many of them are temporary. The glacial history of Svalbard has been disputed, but the distribution of glaciers since 1936/1972 and until recent time has been mapped (Kônig et al. 2013). It means that freshwaters younger than 80 years can be roughly dated. The history of older lakes, often situated closer to the coastline, is more uncertain, but mapping of the freshwater fauna along a gradient from the edge of the glacier and to the coastline will likely reflect the colonization history.

Fortunately, there exist some old recordings of the Svalbard freshwater fauna (Brehm 1917, Thor 1930), and the most extensive study dates more than 100 years back to a survey in 1910 (Olofsson 1918). These data, focusing on rotifers and crustaceans, were gathered in the Isfjorden and Van Mijenfjorden area, possessing numerous ponds and a few lakes. Since Olofsson's seminal survey there have only been some scattered studies on crustaceans (e.g., Halvorsen and Gullestad 1976, Jørgensen and Eie 1993 Husman et al. 1978, Kubicek and Terek 1991). Some studies have also specifically addressed the clonal diversity of the widespread and dominant cladoceran Daphnia (Weider and Hobaek 1994) as well as the impact of birds on species and clonal composition (van Geest et al. 2007; Alfsnes et al. 2016). For other compartments of the freshwater fauna, there is even more scarce information, and some groups are hardly recorded, at least not in any systematic manner. Among the insects, there is a strong dominance of Diptera, which is the most species-rich freshwater group in Svalbard, being 122 species at Svalbard and Bear Island (Coulson and Refseth 2004; Coulson 2014). This group is better adapted to the cold and harsh climate in the artic than any other order of insects (Coulson and Refseth 2004).

To fill some of the knowledge gaps of freshwater invertebrates at Svalbard and establish, at least regionally, a kind of "baseline" survey for later studies, zooplankton, meiobenthos and macrobenthos were sampled in a number of localities in August 2014 and 2015. While this only covers the central, western part of the Svalbard Archipelago, this is the area with the highest temperatures owing to the oceanic currents, the highest productivity and diversity, and the region most impacted by both humans and the increased goose populations. It is also the area for which there is some previous data on the freshwater fauna, and thus we believe this should provide a good representation of authenticated version is available online at: http://dx.doi.org/ 10.1007/s00300-018-2340-3. 
122

current freshwater fauna as well as already observed changes at the community or species level since earlier studies (i.e. Olofsson 1918).

The aim of this study was to provide a full report of the species inventory for zooplankton, benthos and meiofauna in the sampled waterbodies. We also provide data for species that have apparently colonized the sites over the past decades. Finally, we related diversity and community composition to the age of the ecosystem and (or key parameters that co-vary to age), which may hint at the rate of colonization over the time span from the oldest to the youngest.

\section{Material and Methods}

Altogether 75 localities were sampled in Svalbard in 2014 and 2015. In the period 18-24 August 2014, sampling was conducted in different parts of Isfjorden: Longyearbyen (2 localities), the gradient Aldegondabreen-Grønfjorden (16), Randvika (12), Barentsburg (2), Ymerbukta (4), Pyramiden (6), Kapp Napier (6) and Diabasodden (2) (Fig. 1). In 2015 (17 - 19 August) 15 localities in Ny-Ålesund area (including six localities along the gradient from the sea and to the glacier Midtre Lovènbreen) and 10 localities along the gradient from Grønfjorden to the glacier Vestre Grønfjordbreen were sampled. These localities also covered the areas sampled in 1910 (Olofsson 1918).

Since the age of the locality was assumed relevant, we made sure that localities along the gradient from the edge of glaciers and to the seashore were represented wherever possible. We focused on the most species-rich groups, Crustacea and Diptera, which was identified to the species level, while the taxonomic resolution for other groups was in cases restricted to higher levels. The composition of the invertebrate communities should presumably be related to important environmental variables such as age, temperature, size, longitude and latitude, elevation, water chemistry and the presence of fish. We also compared our invertebrate inventories with previous (yet more incomplete) studies to document changes that have occurred already and relate diversity to key drivers to possibly predict future changes.

The waterbodies were categorized into four classes according to their size and approximate average depth. The categories were based on an already existing concept presented by CAFF (Conservation of Arctic Flora and Fauna) Freshwater Expert authenticated version is available online at: http://dx.doi.org/ 10.1007/s00300-018-2340-3. 
153 Monitoring Group for Pan-Arctic Monitoring program and from other literature sources

154 (Culp et al. 2012; Rautio et al. 2011). The localities ranged from $4 \mathrm{~m}$ to $166 \mathrm{~m}$ above sea;

155 surface area varied from puddles less than $2 \mathrm{~m}^{2}$ to 460 ha and depths of 0.25 to $37 \mathrm{~m}$.

156 Lake Linnè was the largest and deepest lake. For the analysis we categorized the sites in

157 four classes according to their size; 1 (puddle): $\leq 0.01$ ha, 2 (small pond): 0.01-0.1 ha, 3

158 (large pond): 0.1-1.0 ha, 4: (lake) > 1.0 ha, and three classes according to their average

159 depths $(1: \leq 0.25 \mathrm{~m}, 2: 0.25-1 \mathrm{~m}, 3:>1 \mathrm{~m})$. With a few exceptions, all ponds were

160 shallow and less than $1 \mathrm{~m}$ deep. Depth estimates for the lakes are, however, somewhat

161 rough since they for logistic reasons had to be performed without the use of a boat.

162 Examples of these categories are provided in Fig. 2.

163 The past coverage of glaciers on Svalbard is shown in the digital atlas of "Glaciers 164 on Svalbard” published by the Norwegian Polar Institute

165 (http://svalbardkartet.npolar.no/html5/index.html?viewer=svalbardkartet). The basis for

166 the atlas is three sets of maps showing the distribution of the glaciers created in the

167 period 1936-72, in 1990 and later in the period 2001-2010. Based on the atlas we 168 grouped the localities into four age classes; 1) 2001/2010 to the present (1 locality), 2)

169 1990-2001/2010 (3 localities), 3) 1936/1972-1990 (19 localities) and 4) < 1936-1972

170 (52 localities). The age of the oldest localities may cover a wider span (i.e Velle et al.

171 2011), but in the absence of proper dating we have pooled them into one category that

172 has been without a permanent ice-cover for an extended period.

$173 \mathrm{pH}$ was $>7.0$ in all waterbodies with a mean of 8.5, and a max of 9.5 (small pond,

174 Diabasodden). The lowest $\mathrm{pH}, 7,3$, was recorded in a small pond in Ymerbukta. Most

175 sites had high conductivity (mean 413, max $1750 \mu \mathrm{S} \mathrm{cm}^{-1}$ ). $\mathrm{pH}$, conductivity and

176 temperature were measured by applying Hanna Instruments waterproof tester (HI98129

177 and HI98130).

178 Five ponds/lakes had a fish population. The occurrence of fish (only Arctic charr, 179 Salvelinus alpinus) was categorized as present or absent based on existing knowledge 180 (K. S. Christoffersen and M. Svenning, unpublished data); thus no attempts were made 181 to assess the density or biomass of fish.

182 Zooplankton, macrobenthos and meiobenthos, were sampled from all localities as 183 follows:

This is a post-peer-review, pre-copyedit version of an article published in Polar Biology. The final authenticated version is available online at: http://dx.doi.org/ 10.1007/s00300-018-2340-3. 
Zooplankton was sampled from four habitats: the open water, the littoral zone, the nearsediment layer and the upper sediment layer. In all cases, samples were performed with a 100 mm diameter, 50- $\mu \mathrm{m}$ mesh zooplankton net. For larger sites, a floating device was used to bring the net near the center, and care was taken to sample both from the open waters and the near-bottom and littoral habitats. In very shallow ponds, samples were taken by dragging the net horizontally in the water by walking. When this method was not possible due to the small size or the presence of stones, water was collected in a bucket and then filtered for animals. In the littoral zone, samples were taken with a small net having a long handle. The samples were preserved with $96 \%$ ethanol. In general, the entire sample was washed and prepared to have a total volume of $100 \mathrm{ml}$, and thereafter counted to get the relative species distribution (see below). In samples with high densities subsamples were examined until at least 200 organisms were counted for each group. For identification and taxonomy see Novichkova et al. (2014).

Meibenthos was sampled using a plastic tube that was inserted into the uppermost 3-4 cm of the sediment layer. From each site, 2-3 samples were taken randomly, all representing different meiobenthic habitat substrates if possible, and then pooled. Each sample covered an area of 3 $\mathrm{cm}^{2}$. The samples were preserved with $96 \%$ ethanol and filtered (50- $\mu \mathrm{m}$ mesh) before identification following Dussart and Defaye (1983), Bartsch (2006) and Alekseev and Tsalolikhin (2010).

Macrobenthos samples were taken from the shore to a depth of ca $1.5 \mathrm{~m}$ (or max depth in the more shallow sites). We used a hemispherical scraper (diameter $16 \mathrm{~cm}$, area $0.02 \mathrm{~m}^{2}$, mesh size $0.5 \mathrm{~mm}$ ) and 5-10 samples (depending on the density of organisms) were merged into one sample. Mud and coarse gravel were eliminated before the sample was preserved with $96 \%$ ethanol. Identification was performed according to Wiederholm (1983), Timm (2009) and Makarchenko (2001).

Neither of these samplings allowed for a precise quantitative judgment; hence we applied four "dominance classes" on an ordinal scale to reflect the dominance of species based on frequencies in the individual sample (0: absent, $1:<1 \%, 2: 1-10 \%, 3:>10 \%)$ (Walseng et al. 2006). The relationship between taxa richness and the environmental variables longitude, latitude, elevation, depth, area, age, presence of fish, $\mathrm{pH}$, conductivity and water temperature was analyzed by univariate multiple linear authenticated version is available online at: http://dx.doi.org/ 10.1007/s00300-018-2340-3. 
regression. Due to the high number of possible interactions between environmental

216 variables, interactions were not included in the analysis. Taxa richness was checked for

217 normality and homogeneity of variances. A backward selection procedure was used to

218 exclude predictors from the model $(\mathrm{P}>0.1)$. Elevation and conductivity were log-

219 transformed. For pair-wise comparisons of means of taxa richness in the different age

220 classes, t-tests with Bonferroni correction was applied. Hence, the observed significance

221 level is adjusted for multiple comparisons. The youngest age class only contained one

222 water body. Therefore, the pairwise comparisons were only conducted between age

$223 \quad$ classes 2,3 and 4.

224 The relationships between environmental variables and the invertebrate community

225 from the respective localities were analyzed using unconstrained and constrained

226 ordination techniques. Detrended correspondence analysis (DCA, Hill and Gauch 1980)

227 showed that the first DCA axis spanned a gradient length of 2,9 SD units for the

228 invertebrate community. Due to the relatively long gradient length, we applied the

229 constrained ordination technique canonical correspondence analysis (CCA) in the

230 analysis of the impact of environmental variables on the invertebrate community (cf.

231 Økland 1990). The statistical significance of the relationship between the species or taxa

232 and the set of environmental variables was examined by testing the significance of the

233 canonical axes together with a Monte-Carlo permutation test. The development of a

234 "minimal adequate model” was done by forward selection of environmental variables

235 with a Monte Carlo test (499 permutations). Only variables that made significant

236 independent contributions to the variation in species abundance ( $\alpha=0.05$ level) were

237 included in the model. The dominance scores of the different taxa were used as input

238 data in the CCA- analysis. The following parameters were included in the RDA:

239 longitude, latitude, elevation, depth, area, age, presence of fish, $\mathrm{pH}$, conductivity and

240 water temperature. Elevation and conductivity were transformed $(\log 10(X+1))$. The

241 multivariate regressions were conducted in SPSS Statistics 24 (IBM). The ordination

242 analysis was conducted with the software CANOCO 5.0 (ter Braak and Šmilauer 2012).

This is a post-peer-review, pre-copyedit version of an article published in Polar Biology. The final authenticated version is available online at: http://dx.doi.org/ 10.1007/s00300-018-2340-3. 


\section{Results}

The most prevalent taxa were the nematodes found in 74 of the 75 localities, while

245 Ostracods and tardigrads were found in 51 and 45 localities, respectively (Fig. 3).

246 Altogether 53 taxa were found of which 37 were identified to a species level (Appendix

247 1). The number of taxa in one location varied between 2 and 14 (mean 8.8). The most

248 taxon-rich locality was Lake Solvatn, a nutrient-rich and bird-affected shallow locality close to Ny-Ålesund.

The two most taxon-rich invertebrate groups were crustaceans and chironomids, both constituting 22 and 21 taxa, respectively. Crustaceans were found in both zooplankton and meiobenthos samples and were represented by four groups; Cladocera (8 taxa), Cyclopoida (4 taxa), Calanoida (2 taxa) and Harpactoida (6 taxa) (Appendix 1). On average 4.3 species of crustaceans were found per locality (from zero to 8 species).

The pair-wise comparison revealed that mean taxa richness in age class 2 was significantly lower than that of age class 4 (Fig. 4, t-test with Bonferroni correction, 
274 difference between means $=4.891, \mathrm{p}=0.003)$. The first two CCA axes in the

275 ordination of the invertebrate community had eigenvalues of 0.1925 and 0.1053 ,

276 respectively, and explained $10.8 \%$ of the variation in the species' composition and 47.0

$277 \%$ of the variation in the species-environment relationship (Table 3; Fig. 5). There was

278 a significant relationship between the set of environmental variables and species'

279 composition (i.e. all canonical axes, pseudo- $F=1.9, p=0.002$ ). The "minimal adequate

280 model” resulting from the forward selection included the explanatory variable water

281 body age (pseudo- $F=3.5, p=0.002)$, temperature (pseudo- $F=2.2, p=0.006)$,

282 conductivity (pseudo-F $=2.1, \mathrm{p}=0.002$ ), longitude (pseudo- $\mathrm{F}=2.1, \mathrm{p}=0.002$ ) and

283 latitude (pseudo- $\mathrm{F}=2.1, \mathrm{p}=0.002$ ). The intra-set correlations of environmental

284 variables with the CCA axes (Tab. 3) and the CCA biplot (Fig. 5) showed that the

285 invertebrate community in the water bodies was distributed mainly along a gradient of

286 age and temperature on CCA axis 1. CCA axis 2 was mainly correlated with

287 conductivity (Tab. 1, Fig. 5).

288 Many invertebrate taxa, such as chironomids. sp., E. raboti, D. pulex, $M$.

289 hirsuticornis and L. arcticus were associated with low axis 1 scores (Fig. 5), i.e. the

290 "oldest" sites with the highest temperatures. Other taxa such as Oliveridia tricornis and

291 Diamesa gr. arctica were associated with higher axis 1 scores, i.e. lower age class and

292 temperature. Tardigrada and Nematoda were the "pioneer groups" and the only taxa in

293 age class 1, but they also occurred in the older localities. Examples of taxa associated

294 with low axis 2 scores, that is high conductivity, are Tahidius discipes and

295 Metriocnemis gr. fuscipes, while Micropsectra sp., M. radialis and Apatania zonella

296 are examples of species associated with high axis 2 scores, i.e. low conductivity.

297

As age - or distance from sea or glacier, respectively - was the most important of

298 the environmental variables, we have sorted the occurrence of the different taxa

299 according to the water body age classes (Appendix 1). It appears that Nematoda and

300 Tardigrada are the earliest colonizers of the water bodies, as they are the only

301 invertebrates recorded in age class 1 . In the slightly older water bodies, in age-class 2,

302 one cyclopoid, five chironomids and one annelid appear. The number of taxa in age

303 classes 3 and 4 was 38 and 47, respectively.

304 
Drivers: Among the variables used in our analysis, age appeared to be the most important driver of the observed invertebrate diversity found in 75 freshwater localities situated in the central/western parts of Svalbard. However, CCA (Fig. 5) explained a low

309 fraction of the total variance, and only $10.8 \%$ of the variation was explained by the first two axes. This could partly be owing to the limited number of variables included, but it could also be a result of more stochastic events. The interpretation of age and temperature should be judged with caution since other potentially important parameters

314 included. Sites at lower altitudes not only have a higher age and higher temperature, 315 which is a minimum factor at high latitudes, they are also often surrounded by vegetation, promoting dissolved organic matter that could shield off UV-radiation in these otherwise clear ponds (cf. Hessen et al. 1996). They attract grazing birds that could serve a dual role by fertilizing the ponds as well as being vectors of invertebrates, promoting species and clonal richness (van Geest et al. 2007; Alfsnes et al. 2016). Disentangling age from these covariates is not straightforward, and likely several of these factors may contribute to the observed community composition and diversity. Clearly a faster colonization would be expected for flying insects compared with other groups, but still age will likely play a major role simply due to the available time-span for colonization.

No doubt predation could also affect richness and community composition. With regard to fish, Arctic charr (S. alpinus) is the only species present at Svalbard, and then only in 5 of the surveyed localities. These are also generally larger and deeper than fishless sites, again opening for confounding effects, but we found no statistical effect on fish (as a presence-absence nominal category) in our study.

Thus, it is hard to arrive at strong predictors of species distribution and community composition, but some intriguing patterns, notably related to age, could be detected. The main aim was, however, to provide a "baseline", at least regionally, for key freshwater taxa, and below we thus discuss the species and communities in more detail.

Community and species responses: Nematodes and tardigrades were the only taxa represented in the newly established waterbody in front of the glacier in Grønfjorden. Both groups include extremely tolerant forms and have successfully adapted to nearly all 
337

ecosystems. Free-living nematodes are a major component of both pelagic and meiofaunal communities (Majdi and Traunspurger 2015) and 95 species have been reported from Spitzbergen inhabiting mosses, soil and water (Coulson 2014). Even from debris-covered glaciers, several species have been reported (Azzoni et al. 2015).

Likewise, tardigrades constitute a permanent and ubiquitous faunal component of polar regions (Zawierucha et al. 2016) and have also been recorded in supraglacial ecosystems like small puddles at glaciers (De Smet and van Rompu 1994, Hodson et al. 2008). Due to their size and robustness, this group can easily spread to nearby locations by wind and birds. This group has a high tolerance to harsh conditions, such as dehydration, freezing and radiation, and can survive either in anabiosis or an active state where morphological, physiological and molecular adaptations may occur (Wełnicz et al. 2011). According to Pugh and McInnes (1998), arctic tardigrades was probably derived from wind-blown Nearctic propagules that colonized the region during the Holocene.

Chironomids are better adapted to the arctic environment than any other insect group and are hence an important contributor to arctic diversity (Coulson et al. 2014). As other winged insects they are capable of dispersal and rapid colonization. In age-class 2 localities (covered with ice until 1990), we recorded five species, among others Oliveridia tricornis, which was associated with low temperature (CCA- ordination, Fig. 5). It has a rather low-temperature optimum and is characteristic of ultra-oligotrophic lakes (Coffman et al. 1986; Luoto et al. 2015). According to Brooks and Birks (2004), Oliveridia sp was the only repentant of chironomdes found in a glacier-fed lake (Lake Birgervatnet) on the West coast of Spitzbergen. We recorded the species in a very clean pond formed from a river not far from the Aldegondabreen glacier.

Other early colonizers or pioneer species were the cyclopoid copepod Cyclops abyssorum and a representative for the phylum Annelida (Lumbricillus sp.), both represented in age-class 2. C. abyssorum was the most common copepod in our study, found in nearly half of the localities. Its preference for cold sites is confirmed by its presence on the mainland Norway, where it is most abundant in alpine lakes (situated > $1000 \mathrm{~m}$ above sea) and it is also among the most common copepods in the Alps (Jersabek 2001).

Localities formed in the period $1932-1990$ or prior to this contained most taxa 
among the surveyed sites, and the diversity differed only marginally between these categories, suggesting quite a fast colonization. The localities are, however, closely situated, and repeated transmission of species by birds is likely. For the cladocera, which has asexual formation and resting stages tolerant to freezing and desiccation, wind is also a likely spreading mechanism (Bennike 1999, Incagnone et al. 2015), which is especially effective for small distances in-between sites. Finally, humans may also serve as vectors related to transportation, tourism and scientific fieldwork (Waterkeyn et al. 2010; Incagnone et al. 2015).

Conductivity was an important driver along axis 2, most probably due to high marine impact because of the close distance to the sea. The harpacticoid Tahidius discipes and the annelid Marionina sp. were both strongly associated with high conductivity. T. discipes is a brackish water species (Song et al. 2009), while Marionina sp, among others, includes two species (M macgrathi and M. ulstrupae) that live on wave-exposed rocky shores (Healy 2007). Micro sp., Micropsectra radiali and the trichoptera Apatania zonella were, in contrast, strongly associated with low conductivity. The latter is associated with the outlet from lakes (Lods-Crozet et al. 2007).

The diversity assessed in this study cover taxa down to species level. A closer examination of taxa that may cover species-complexes like Daphnia cf. pulex (Vergilino et al. 2011) and Chydorus sphaericus (Belyaeva \& Taylor, 2009) could have revealed a somewhat higher diversity but would have required molecular analysis. This also holds for clonal diversity, which may clearly add another level of variance to species diversity for the cladocerans, which often are obligate asexual at these high latitudes. Daphnia encompasses a species complex with high clonal diversity (Sarnelle and Wilson 2004). Alfsnes et al. (2016) recorded the highest species and clonal diversity of Daphnia in nutrient-rich and bird-impacted localities at Svalbard and concluded, based on comparisons with data from the same localities in 1992, that increased species and clonal changes could likely be attributed to climate change and increased bird impacts.

The strong increase in temperatures and extended growing season over the past few decades in the high Arctic (Holm et al. 2012; Xu et al. 2013) will undoubtedly affect freshwater ecosystems with respect to productivity, community composition and the establishment of new species. For example, five copepods and two cladocerans new 
to Svalbard were recorded during our samplings: Diacyclops abyssicola, Epactophanes richardi, Geeopsis incisipes, Nitokra spinipes, Diaptomus sp., Alona werestchagini and Polyphemus pediculus (details in Dimante-Deimantovica et al. in prep). Epactophanes richardi was the most common of the newcomers found in 15 localities, often in high number. The others were all found in less than four localities, but then commonly in high number. It should be noted, however, that since previous studies to our knowledge did not search specifically for harpacticoid species, "new to Svalbard” may not, in this case, imply that they have become established over the past 100 years.

Among cladocerans, a recent and prominent trend is a widespread establishment of Bosmina longispina. This is by far the most common species in mainland lakes in Norway (Hessen and Walseng 2006) but has previously not been positively identified at Svalbard. We cannot exclude the possibility that it has been mistaken for $B$. longirostris for which there exists a couple of observations (Zawisza and Szeroczynska 2011; Luoto 2015). Neither of these species was recognized by Olofsson (1918), and since $B$. longispina is now occurring in some of the sites he visited as well as 15 of the localities that were sampled during our campaign in 2014/15, it very likely has benefited from the elevated temperatures and extended growing season. None of the previously recorded species has disappeared; hence the total species richness will potentially continue to increase over the coming years.

In some of the fishless ponds, truly planktonic species were only found in a nearbottom layer. It appears that these species have rather abandoned the pelagic zone due to the heavy pressure of the Daphnia population. Some of the recorded species were rare and found in one or only a few localities, while others were common and could either be widespread or the occurrence could vary geographically as for example the cladoceran Macrothrix hirsuticornis and the copepod Eurytemora raboti. These species were most common in the northern part of the study area, i.e. Billefjorden and Ny-Ålesund. Here, they occurred in $>50 \%$ of the localities, while the corresponding figure for Grønfjorden further south was $<20 \%$.

Generally, all macrobenthic communities in Svalbard have a simple and very similar taxonomical structure, with dominance of chironomids larvae (Brooks and Birks 2004, Lods-Crozet et al. 2007). Except for M. insignilobus which was for the first time reported from Svalbard in 2011 (Velle et al. 2011), most taxa seem to be rather common. 
433 To evaluate possible recent changes in abundance and frequency, we compared our data 434 on chironomids with data from a study in 23 lakes situated in western Svalbard sampled 435 in 1993 (Brooks and Birks 2004). The species were here presented as

436 abundance/frequency from the upper $1 \mathrm{~cm}$ of the sediment. The two most

437 frequent/abundant taxa of his study, Micropsectra radialis and Orthocladius sp, were 438 less common in our study. On the other hand, Paratanytarsus austriacus had become 439 much more abundant and found in 30 localities in our study. Whether this reflects 440 weather, climate or stochastic events remains an open question.

441 While not a true "baseline” study in the sense of an inventory prior to 442 anthropogenic effects, our study presents the hitherto most comprehensive data on 443 invertebrate freshwater diversity at Svalbard, and in areas where there are most biotic 444 activity, ponds and likely highest diversity. It may thus serve as a reference for future 445 changes but also demonstrate that climate change, both directly and indirectly, notably 446 via increased geese density and activity (Hessen et al. 2017), affect the species 447 composition and diversity of these high Arctic ecosystems. Finally, our study also 448 clearly demonstrates a diversity gradient related to ecosystem age or parameters related to 449 age (like productivity), which may hint at the rate of colonization over the time span 450 from the oldest to the youngest localities. 


\section{Literature}

Alekseev VR, Tsalolikhin SY (ed.) (2010) Guide of freshwater zooplankton and zoobenthos of European Russia. Zooplankton 1. KMK Scientific Press, Moscow, pp 495 (in Russian)

Alfsnes K, Hobæk A, Wieder LJ, Hessen DO (2016) Birds, nutrients and climate change: mtDNA haplotype diversity of Arctic Daphnia on Svalbard revisited. Polar Biol 39(8):14251437

Azzoni RS, Franzetti A, Fontaneto D, Zullini A, Ambrosini R (2015) Nematodes and rotifers on two Alpine debris-covered glaciers. Italian Journal of Zoology 82(4):616-623

Bartsch I (2006) Halacaroidea (Acari): A guide to marine genera. Organisms, Diversity and Evolution 6, Electronic Supplement 6:1-104

Bennike, O (1999) Colonization of Greenland by plants and animals after the last ice age: A review. Polar Rec 35(195):323-336

Bhatt US, Walker DA, Raynolds MK, Comiso JC, Epstein HE, Jia GS et al. (2010)

Circumpolar Arctic tundra vegetation change is linked to sea ice decline. Earth Interact 14:120 Brehm V (1917) Entomostraken aus Spitzbergen. Arch Hydrobiol Plankt 11:609-623

Brehm V (1917) Entomostraken aus Spitzbergen. Arch Hydrobiol Plankt 11:609-623

Brooks SJ, Birks HJB (2004) The dynamics of Chironomidae (Insecta: Diptera) assemblages in response to environmental change during the past 700 years on Svalbard. J Paleolimnol 31:483-498

Christoffersen KS, Amsinck SL, Landkildehus F, Lauridsen TL, Jeppesen E (2008) Lake flora and fauna in relation to ice-melt, water temperature and chemistry at Zackenberg. Adv Ecol Res 40:371-389 
488 Coffman WP, Cranston PS, Oliver DR, Sæther OA (1986) The pupae of Orthocladiinae

489 (Diptera: Chironomidae) of the Holarctic region-Keys and diagnoses. In: Wiederholm T

490 (ed.) Chironomidae of the Holarctic region. Keys and Diagnoses. Part 2. Pupae. Ent. stand.

491 Suppl. 28, pp 147-296

492

493 Coulson SJ, Refseth D (2004) The terrestrial and freshwater invertebrate fauna of Svalbard

494 (and Jan Mayen). In Prestrud P, Strøm H, Goldman H (ed.) A catalogue of the terrestrial and

495 marine animals of Svalbard. Skrifter 201, Norwegian Polar Institute, Tromsø, pp 57-122

496

497 Coulson SJ, Convey P, Aakra K, Aarvik L, Ávila-Jiménez ML, Babenko A et al. (2014) The

498 terrestrial and freshwater invertebrate biodiversity of the archipelagoes of the Barents Sea;

499 Svalbard, Franz Josef Land and Novaya Zemlya. Soil Biol Biochem 68:440-470

500

501 Culp JM, Goedkoop W, Lento J, Christoffersen KS et al. (2012) Arctic freshwater

502 biodiversity monitoring plan. CAFF Monitoring Series Report, no. 7

503

504

De Smet WH, van Rompu EA (1994) Rotifera and Tardigrada from some cryoconite holes on

505 a Spitsbergen (Svalbard) glacier. Belg J Zool 124:27-37

506

507

Dimante-Deimantovica I., Novichkova A. Chertoprud, E. Walseng B in prep. The appearance of new micro-crustacean species in High Arctic (Svalbard, Norway)

509

510

Dussart BH, Defaye D (1983) Répertoire mondial des Crustacés Copépodes des eaux

511

intérieures. Calanoïdes. CNRS Bordeaux, Paris, pp 224

512

513

Halvorsen G, Gullestad N (1976) Freshwater Crustacea from some areas of Svalbard. Arch

514

Hydrobiol 78:383-395

515

516

Healy B (2007) New species of Marionina (Oligochaeta: Enchytraeidae) from a wave-exposed

517 rocky shore in SE Ireland. J Nat Hist 30 (9):1287-1295 
519 Hessen DO (1996) Competitive trade-off strategies in Arctic Daphnia linked to melanism and

520 UV-B stress. Polar Biol 16: 573-579

521

522 Hessen DO, Walseng B (2008) The rarity concept and the commonness of rarity in freshwater 523 zooplankton. Freshw Biol 53:2026-2035

524

525

526

527

528

529

530

531

532

533

534

535

536

537

538

539

540

541

542

543

544

545

546

547

Hessen DO, Tombre IM, van Geest G, Alfsnes K (2017) Global change and ecosystem connectivity: How geese link fields of central Europe to eutrophication of Arctic freshwaters. Ambio 46:1-40

Hill MO, Gauch HG (1980) Detrended correspondence analysis: An improved ordination technique. Vegetatio 42:47-58

Hodson A, Anesio A, Tranter M, Fountain A, Osborn M, Priscu J, Laybourn-Parry J, Sattler B (2008) Glacial ecosystems. Ecol Monogr 78:41-67

Holm TM, Koinig KA, Andersen T, Donali E, Hormes A, Klaveness D, Psenner R (2012) Rapid physicochemical changes in the high Arctic Lake Kongressvatn caused by recent climate change. Aquat Sci 74 (3):385-395

Husmann S, Jacobi HU, Meijering MPD, Reise B (1978) Distribution and ecology of Svalbard's Cladocera. Verh Internat Verein Limnol 20:2452-2456

IPCC (2013) Summary for Policymakers. In: Climate Change 2013: The Physical Science Basis. Contribution of Working Group I to the Fifth Assessment Report of the Intergovernmental Panel on Climate Change. Stocker TF, Qin D, Plattner G-K, Tignor M, Allen SK, Boschung J, Nauels A, Xia Y, Bex V, Midgley PM (ed). Cambridge University Press, Cambridge, United Kingdom and New York, NY, USA, pp 27

Ims RA, Alsos IG, Fuglei E, Pedersen ÅØ, Yoccoz NG (2014) An Assessment of MOSJ: The state of the terrestrial environment in Svalbard. Report series / Norwegian Polar Institute 144: 
551

Incagnone G, Marrone F, Barone R, Robba L, Naselli-Flores L (2015) How do freshwater organisms cross the “dry ocean”? A review on passive dispersal and colonization processes with a special focus on temporary ponds. Hydrobiol 750 (1):3-123

Jersabek, CD, Brancelj A, Stoch F, Schabetsberger R (2001) Distribution and ecology of copepods in mountainous regions of the Eastern Alps. Hydrobiol 453/454:309-324

Jørgensen I, Eie JA (1993) Utbredelsen av zooplankton, bunndyr og fisk i innsjøer og dammer på Moselhalvøya, Svalbard. NINA forskningsrapport 045, pp 1-25

Kubícek F, Terek J (1991) Zooplankton Svalbardu (Spicbergy). Biológia (Bratislava) 46:873879

König M, Kohler J, Nuth C (2013) Glacier Area Outlines - Svalbard. Norwegian Polar Institute. https://doi.org/10.21334/npolar.2013.89f430f8

Lods-Crozet B, Lencioni V, Brittain JE, Marziali L, Rossaro B (2007) Contrasting chironomid assemblages in two high Arctic streams on Svalbard. Fund Appl Limnol 170(3):211-222

Luoto TP, Oksman M, Ojala AEK (2015) Climate change and bird impact as drivers of High Arctic pond Deterioration. Polar Biol 38:357-368

Majdi N, Traunspurger W (2015) Free-Living Nematodes in the Freshwater Food Web: A Review. J Nematol 47(1):28-44

Makarchenko EA (2001) Chironomidae. In: Key to freshwater invertebrates of Russia and adjacent lands. Vol. 4. pp 210-295

Novichkova A, Chertoprud E, G1'slason G (201420 Freshwater Crustacea (Cladocera, Copepoda) of Iceland: Taxonomy, ecology, and biogeography. Polar Biol 37:1755-1767 
582 Olofsson O (1918) Studien über de Süsswasserfauna Spitzbergens. Beitrag zur Systematik, 583 Biologie under Tiergeographie der Crustaceen und Rotatorien. Zoologiska Bidrag från 584 Uppsala 6: pp 648

585

586 Pugh PJA, McInnes SJ (1998) The origin of Arctic terrestrial and freshwater tardigrade. Polar 587 Biol 19:177-182

588

589

Quinlan R, Douglas MSV, Smol JP (2005) Food web changes in arctic ecosystems related to 590 climate warming. Global Change Biology 11:1381-1386

591

Rautio M, Dufresne F, Laurion I, Bonilla S, Vincent WF, Christoffersen KS (2011) Shallow

593 freshwater ecosystems of the circumpolar Arctic. Ecoscience 18:204-222

594

595

Sarnelle O., Wilson A-E (2005) Local adaptation of Daphnia pulicaria to toxic

596

cyanobacteria. Limnol Oceanogr 50:1565-1570

597

598

Smol JP, Wolfge A, Birks HJB, Douglas MSV, Jones VJ et al. (2005) Climate-driven regime 599 shifts in the biological communities of arctic lakes, PNAS,102 (12):4397-4402

600

601

602

Smol JP, Douglas MSV (2007) Crossing the final ecological threshold in high Arctic ponds.

Proc Natl Acad Sci 104:12395-12397

603

604

605

Song SJ, Park J, Kwon B-O, Ryu J, Khim JS. (2012) Ecological checklist of the marine

606

607

ter Braak CJF, Šmilauer P (2012) Canoco reference manual and user's guide: Software for

608 ordination, version 5.0. Microcomputer Power Ithaca, USA, pp 496

609

610 611 brackish-water harpacticoid copepod fauna in Korean waters. Zool Stud 51:1397-1410 
613 Thor S (1930) Beiträge zur Kenntnis der invertebraten Fauna von Svalbard. Skrifter om

614 Svalbard og Ishavet 27:1-156

615

Van Geest GJ, Hessen DO, Spierenburg P, Dahl-Hansen GA, Christensen G, Faerovig PJ,

617 Brehm M, Loonen MJ, Van Donk E (2007) Goose-mediated nutrient enrichment and

618 planktonic grazer control in Arctic freshwater ponds. Oecologia 153(3):653-662

619

620

Velle G, Kongshavn K, Birks HJB (2011) Minimizing the edge-effect in environmental

621 reconstructions by trimming the calibration set: Chironomid-inferred temperatures from

622 Spitsbergen. The Holocene 21(3):417-40

623

624 Walseng B, Halvorsen G, Schartau AK, Hessen DO (2006) The concept of zooplankton;

625 major contribution from littoral species to species richness in lakes. Limnol and Oceanogr

626 51(6):2600-2606

627

628 Waterkeyn A, Vanschoenwinkel B, Elsen S, Anton-Pardo M, Grillas P, Brendonck L (2010)

629 Unintentional dispersal of aquatic invertebrates via footwear and motor vehicles in a

630 Mediterranean wetland area. Aquatic Conserv: Mar Freshw Ecosyst 20:580-587

631

632 Weider L, Hobaek A (1994) Molecular biogeography of clonal lineages in a high-Arctic

633 apomictic Daphnia complex. Mol Ecol 3:497-506

634

635 Wełnicz W, Grohme MA, Kaczmarek L, Schill RO, Frohme M (2011) Anhydrobiosis in

636 tardigrades - the last decade. Journal insect physiol 57(5):577-583

637

638 Wiederholm T (ed.) (1983) Chironomidae of the Holarctic region. Keys and diagnoses. Part. 1.

639 Larvae // Ent. Scand. Suppl. 19. Lund, pp 451

640

641 Xu L, Myneni RB, Chapin III FS, Callaghan TV et al. (2013) Temperature and vegetation

642 seasonality diminishment over northern lands. Nazture Climate Change 3:581-586 
644 Zawierucha K, Zmudczyńska-Skarbek K, Kaczmarek L, Wojczulanis-Jakubas K (2016) The

645 influence of a seabird colony on abundance and species composition of water bears

646 (Tardigrada) in Hornsund (Spitsbergen, Arctic). Polar Biol 39(4):713-723

647

648 Zawisza E, Szeroczsyska K (2011) Cladocera species composition in lakes in the area of the

649 Hornsund Fjord (Southern Spitsbergen)—preliminary results. Knowledge and Management of 650 Aquatic Ecosystems 402:4

651

652 Økland RH, Eilertsen O (1994) Canonical correspondence analysis with variation

653 partitioning: Some comments and an application. J Veg Sci 5:117-126

654

655 


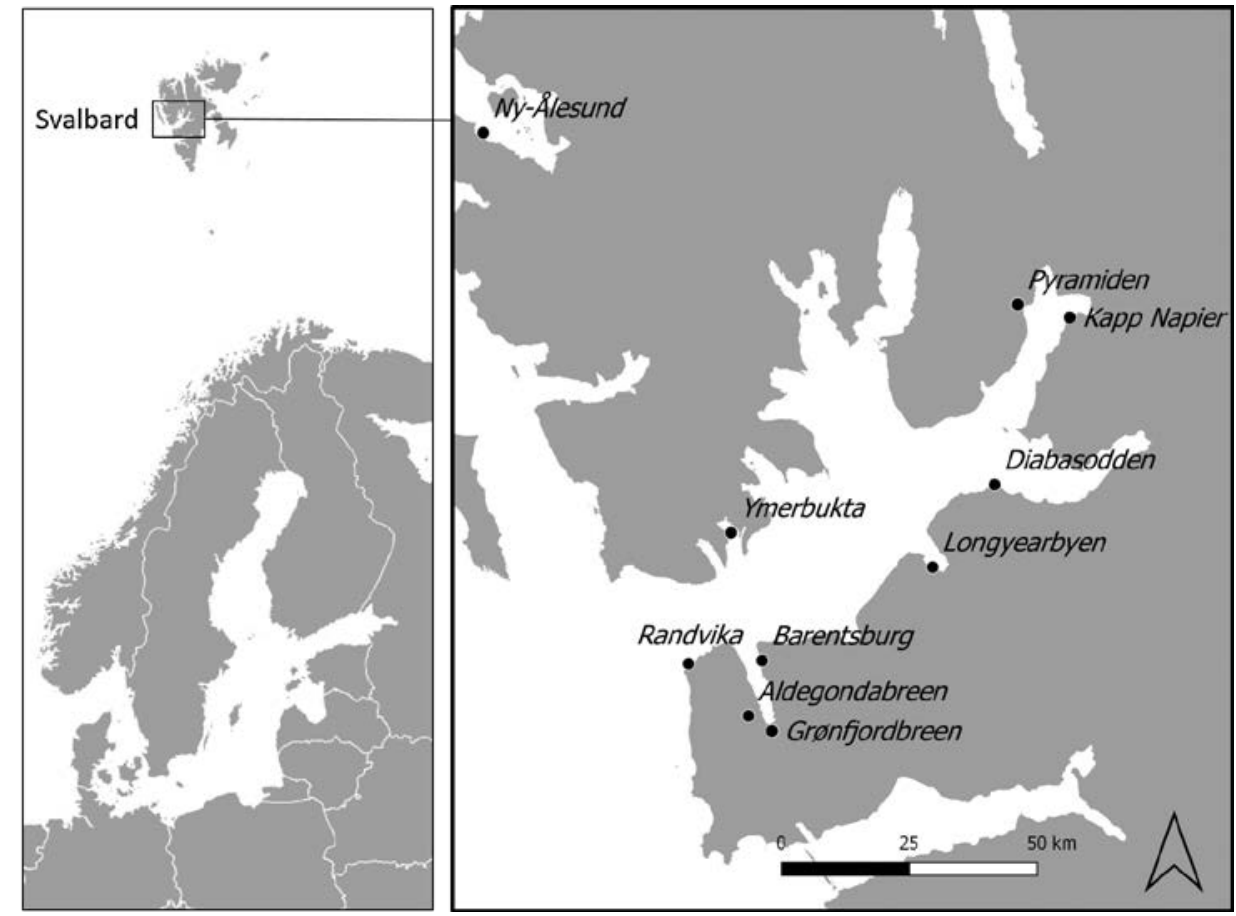

672

673

674

675

676

677

678

679

680

681

682

683

684

685

686

687
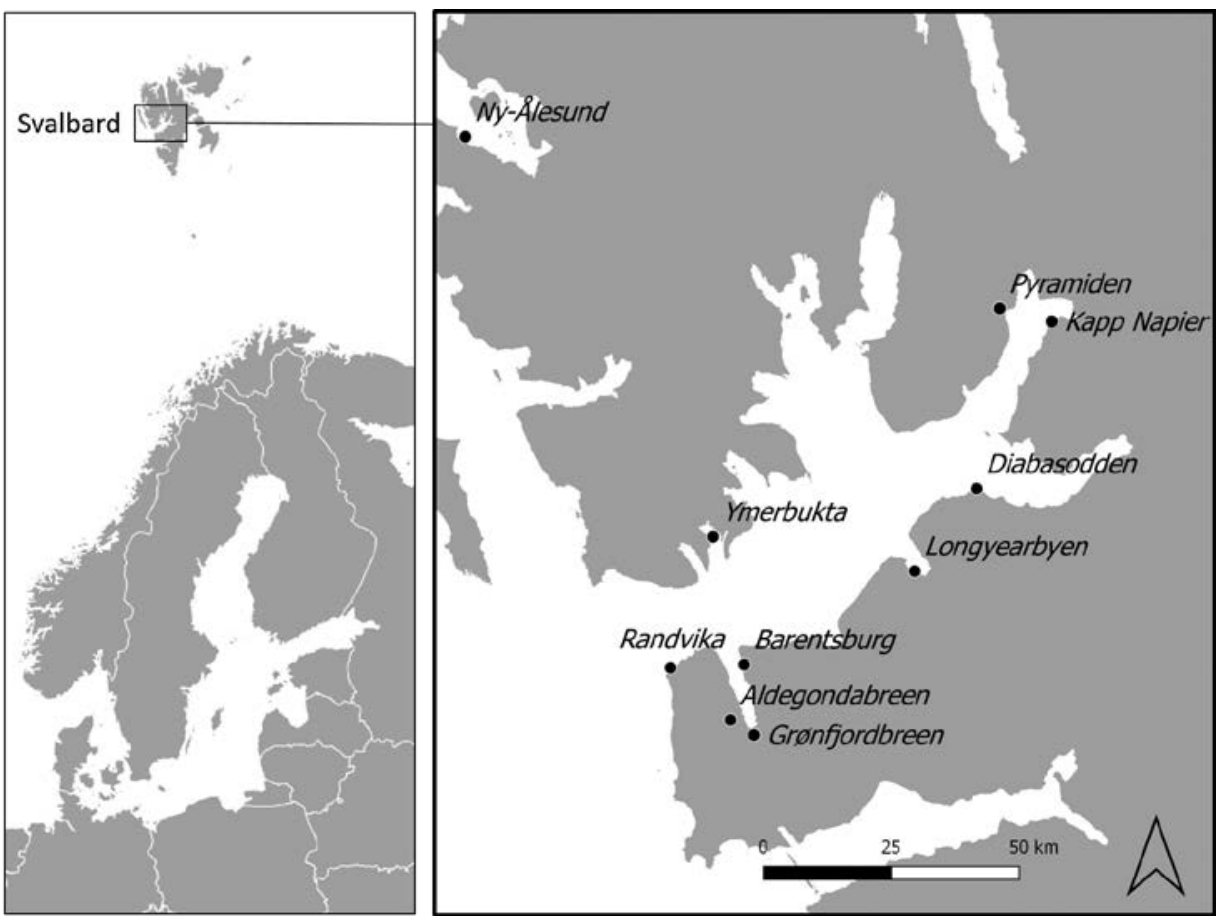

689

Fig. 1. An overview over the investigated areas in Svalbard, Spitsbergen, in 2014 and 690 2015.

691

692

693 

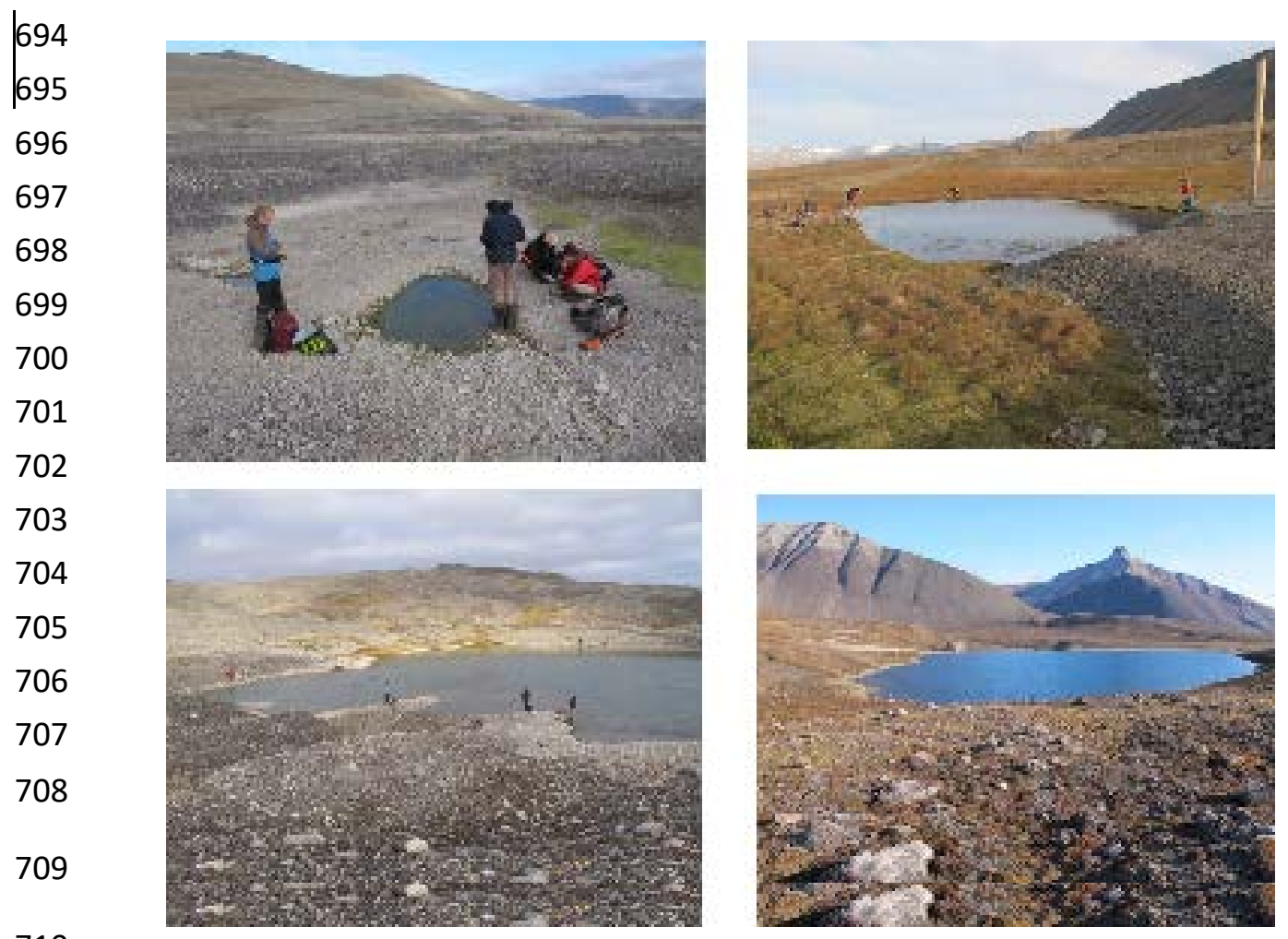

710

Fig. 2. Examples of puddle (Aldegondabreen glacier up left), small pond (Longyearbyen up right), large pond (Aldegondabreen glacier down left) and a lake west of Pyramiden.

713 Photos: Bjørn Walseng

714 
715

717

718

719

720

721

722

723

724

725

726

727

728

729

730

731

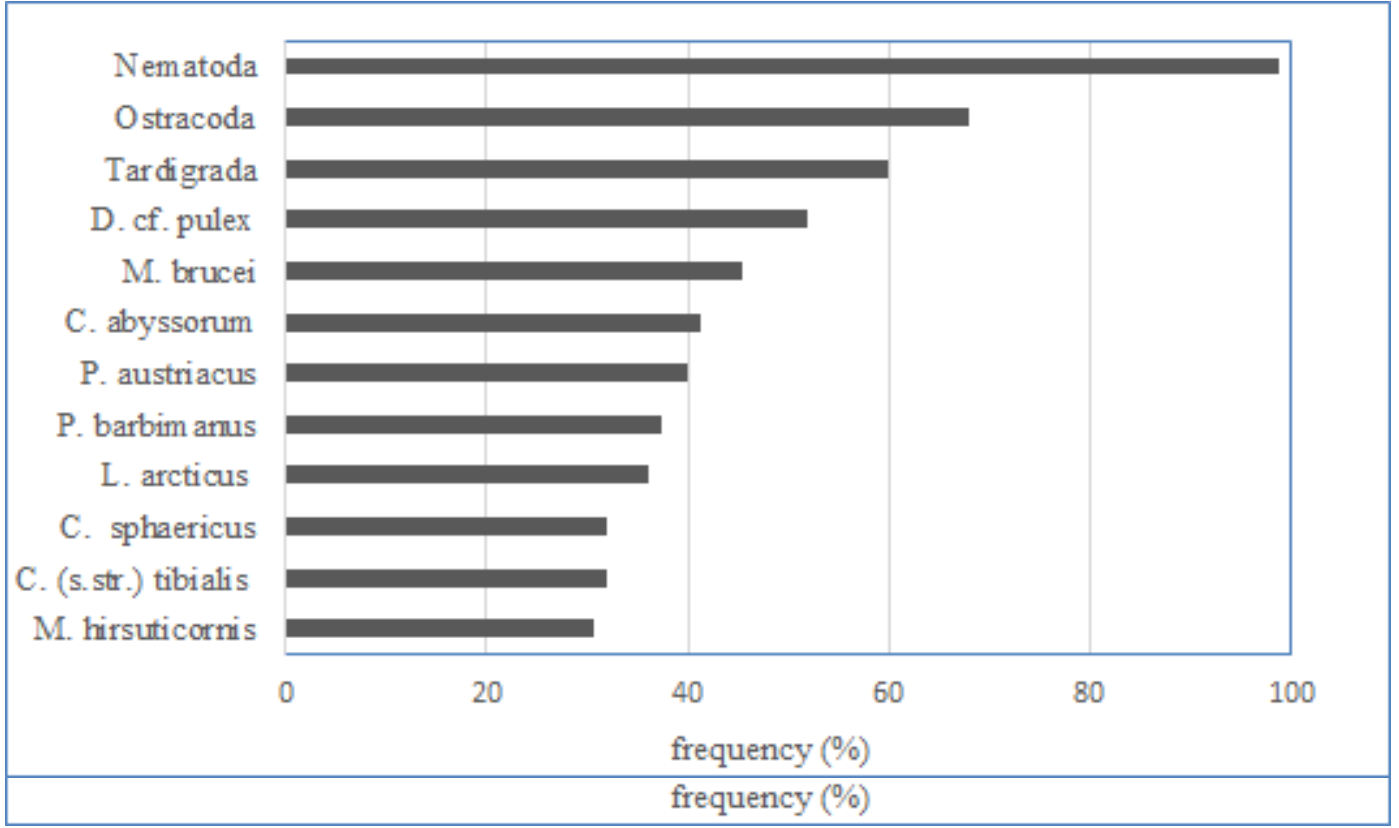

Fig. 3. Taxa which occurred in more than $30 \%$ of the localities $(n=75)$. 
Fig. 4. Box-plot showing invertebrate taxa richness in four groups of water bodies according to age (1: 2001/2010 to the present, 2: 1990-2001/2010, 3: 1936/1972-1990 and 4: < 1936/1972). For an explanation of water body age class, see material and methods section. Different letters above columns indicate a significant difference between means (t-test with Bonferroni correction, $\mathrm{p}<0.05$ ). The youngest age-class only contained one water body. Hence, a pairwise comparison was only conducted between age-classes

757

758 

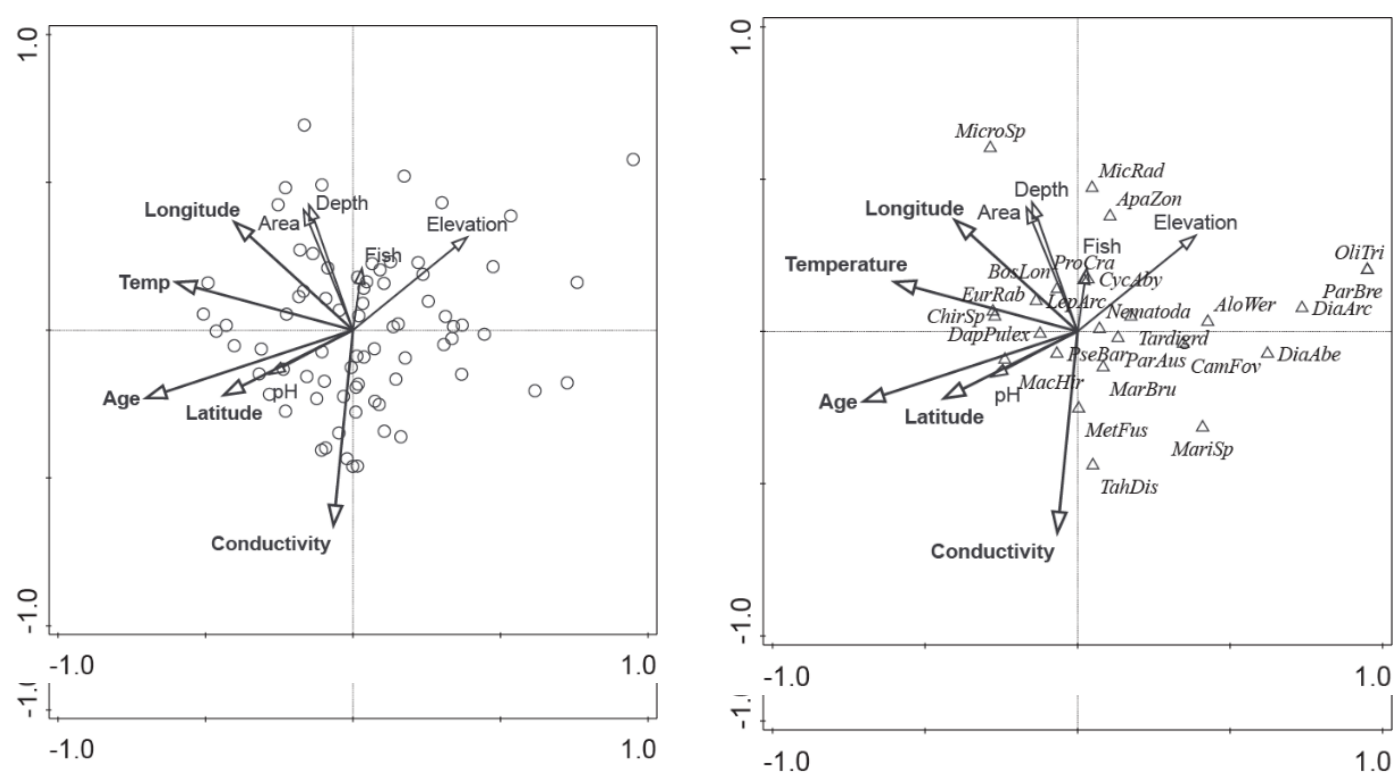

Fig. 5. CCA of the invertebrate community in the surveyed water bodies on Svalbard. Left panel: CCA-ordination plot of the 75 study sites. Right panel: CCA-ordination plot of invertebrate taxa showing the 25 best fitting invertebrate taxa in the ordination space. Environmental variables included in both plots are both significant (in bold: age, temperature, conductivity, longitude and latitude) and non-significant variables from the minimal model (all other environmental variables). Species are abbreviated as MicroSp: Micropsectra sp., MicRad: Micropsectra radialis, ApaZon: Apatania zonella, OliTri: Oliveridia tricornis, ParBre: Paraphaenocladius brevinervis, DiaArc: Diamesa gr. arctica, AloWer: Alona werestschagini, Nematoda: nematodes, CycAby: Cyclops abyssorum, ProCra: Procladius crassinervis, LepArc: Lepidurus arcticus, BosLon: Bosmina longispina, DapPulex: Daphnia pulex, ChirSp: Chironomus sp., EurRab: Eurytemora raboti, MacHir: Macrothrix hirsuticornis, PseBar: Psectrocladius barbimanus, Tardigrd: tardigrades, ParAus: Paratanytarsus austriacus, CamFov: Camisia 
Tab 1. Correlation coefficient and significance level e (Pearson correlation) for longitude, latitude, elevation, depth class, area class, water body age class,

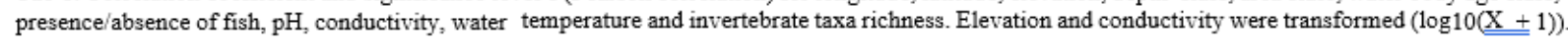
${ }^{* *}$ Correlation is significant at the 0.01 level. ${ }^{*}$ Correlation is significant at the 0.05 level. 牛

\begin{tabular}{|c|c|c|c|c|c|c|c|c|c|c|c|}
\hline & Longitude & Latitude & Elexation & Depth class & Area class & Age class & Fish & $\mathrm{pH}$ & Conductivity & Temperature & $\begin{array}{l}\text { Taxon } \\
\text { tichness }\end{array}$ \\
\hline Longitude & 1 & & & & & & & & & & \\
\hline Latitude & $-0.257^{*}$ & 1 & & & & & & & & & \\
\hline Elevation & $-0.302 * *$ & 0.171 & 1 & & & & & & & & \\
\hline Depth class. & -0.144 & 0.099 & 0.083 & 1 & & & & & & & \\
\hline Area class & -0.136 & 0.141 & 0.089 & $0.905^{* *}$ & 1 & & & & & & \\
\hline age & 0.1306 & $0.296^{* *}$ & -0.226 & 0.111 & 0.100 & 1 & & & & & \\
\hline Fish & -0.031 & -0.211 & -0.145 & $0.325^{* *}$ & $0.357 * *$ & 0.073 & 1 & & & & \\
\hline $\mathrm{pH}$ & 0.123 & 0.189 & 0.084 & 0.194 & 0.126 & 0.073 & 0.050 & 1 & & & \\
\hline Conductivity & 0.120 & 0.176 & $-0.369^{* 8}$ & $-0.363^{* *}$ & $-0.410 * *$ & -0.031 & -0.003 & 0.115 & 1 & & \\
\hline Temperature & 0.227 & -0.070 & $-0.310^{* * 8}$ & 0.061 & 0.034 & $0.403 * *$ & -0.046 & -0.023 & -0.042 & 1 & \\
\hline $\begin{array}{l}\text { Taxon } \\
\text { richness }\end{array}$ & 0.005 & 0.171 & 0.013 & 0.133 & 0.162 & $0.488 * *$ & -0.007 & 0.146 & -0.063 & 0.193 & 1 \\
\hline
\end{tabular}

Tab 2. Parameter estimates for multiple regression models relating invertebrate taxa richness to longitude, latitude, elevation, depth class, area class, water body age class, presence/absence of fish, $\mathrm{pH}$, conductivity and water temperature. For an explanation of depth-, area- and age-class, see methods chapter. Elevation and conductivity were transformed $(\log 10(\mathrm{x}+1))$. A backward selection procedure was used to select predictors and two-way interactions from the full model $(\mathrm{p}>0,1)$. However, none of the interactions were significant.

\begin{tabular}{lllcc}
\hline & \multicolumn{3}{c}{ Estimate $( \pm \mathrm{SE})$} & \\
Response variable & Coefficients & & t-value & $p$ \\
\hline Invertebrate taxon richness & Intercept & $1.224(1.623)$ & 0.754 & 0.453 \\
& & & & \\
& Age & $2.107(0.441)$ & 4.779 & 0.000
\end{tabular}


Tab. 3. Results of the CCA of the taxonomical composition of the invertebrate community in lentic water bodies on Svalbard. Also given are intra-set correlations of environmental variables with CCA axes-

\begin{tabular}{|c|c|c|c|c|c|}
\hline & Axis 1 & Axis 2 & Axis 3 & Axis 4 & Total \\
\hline Figenvalıes & 0.1975 & 010.5 & 00867 & 0.0712 & 27664 \\
\hline Pseudo-canonical correlation & 0.8338 & 0.7462 & 0.7066 & 0.7666 & \\
\hline Explained variation (cumulative) & 6.96 & 10.76 & 13.88 & 16.45 & \\
\hline Explained fitted variation & 30.41 & 47.04 & 60.67 & 71.92 & \\
\hline Sum of all eigenvalues & & & & & 2.7664 \\
\hline Sum of all canonical eigenvalues & & & & & 0.63 \\
\hline $\begin{array}{l}\text { Tntra-set correlations of } \\
\text { environmental variables with axe }\end{array}$ & Axis 1 & Axis 2 & Axis 3 & Axis 4 & \\
\hline Longitude & -0.4017 & 0.3647 & - & -0.4355 & \\
\hline Latitude & -0.4378 & - & - & 0.4514 & \\
\hline Elevation & 0.3864 & 0.314 & 0.3466 & 0.1075 & \\
\hline Depth & -0.1671 & 0.4061 & 0.3471 & 0.0778 & \\
\hline Area & -0.1491 & 0.4232 & 0.2791 & -0.0555 & \\
\hline Age & -0.7016 & - & 0.1707 & -0.4507 & \\
\hline Fish & 0.0302 & 0.2073 & 0.0573 & -0.2888 & \\
\hline $\mathrm{pH}$ & -0.282 & - & 0.2918 & 0.2865 & \\
\hline Conductivitv & -0.0662 & - & - & -0.0701 & \\
\hline Temperature & -0.5999 & 0.1621 & 0.4216 & -0.0301 & \\
\hline
\end{tabular}


Appendix 1. Coordinates, surface area (km2), elevation (m asl) and depth categories (1: <

\begin{tabular}{|c|c|c|c|c|c|c|c|c|c|c|c|}
\hline Loc & East & North & Area km² & $\mathrm{m}$ asl & depth & Loc & East & North & Area $\mathrm{km}^{2}$ & $\mathrm{~m}$ asl & depth \\
\hline 1 & 1545,8 & 7812,2 & 0,0000045 & 13 & 1 & 52 & 1612,2 & 7839,2 & 0,0002 & 52 & 2 \\
\hline 5 & 1542,4 & 7813,1 & 0,00039 & 8 & 2 & 53 & 1607,1 & 7838,4 & 0,027 & 166 & 3 \\
\hline 6 & 1411,1 & 7759,5 & 0,0000019 & 12 & 1 & 54 & 1644,1 & 7838,3 & 0,017 & 6 & 1 \\
\hline 7 & 1411,0 & 7759,4 & 0,0000019 & 18 & 1 & 55 & 1644,5 & 7838,3 & 0,000105 & 8 & 2 \\
\hline 8 & 1410,8 & 7759,5 & 0,00002 & 25 & 1 & 56 & 1644,0 & 7838,2 & 0,0065 & 8 & 3 \\
\hline 9 & 1410,1 & 7759,4 & 0,015 & 50 & 3 & 57 & 1644,2 & 7838,1 & 0,00004 & 15 & 1 \\
\hline 10 & 1411,6 & 7759,5 & 0,004756 & 6 & 3 & 58 & 1644,2 & 7837,9 & 0,0003 & 15 & 2 \\
\hline 11 & 1411,7 & 7759,5 & 0,000008 & 8 & 1 & 59 & 1644,6 & 7838,1 & 0,00007 & 10 & 1 \\
\hline 13 & 1410,6 & 7759,2 & 0,000006 & 46 & 1 & 60 & 1620,5 & 7839,1 & 0,00007 & 8 & 1 \\
\hline 14 & 1409,2 & 7759,2 & 0,000015 & 41 & 1 & 62 & 1606,5 & 7821,7 & 0,0004 & 28 & 2 \\
\hline 15 & 1409,0 & 7759,2 & 0,000025 & 41 & 1 & 64 & 1610,1 & 7821,5 & 0,00015 & 4 & 2 \\
\hline 19 & 1408,7 & 7758,9 & 0,000045 & 44 & 1 & 65 & 1152,7 & 7855,4 & 0,0156 & 49 & 3 \\
\hline 21 & 1410,6 & 7759,1 & 0,01075 & 28 & 3 & 66 & 1203,5 & 7854,9 & 0,027 & 18 & 3 \\
\hline 23 & 1411,2 & 7759,1 & 0,006612 & 4 & 3 & 67 & 1204,3 & 7854,3 & 0,00075 & 42 & 2 \\
\hline 25 & 1414,0 & 7758,2 & 0,002 & 5 & 2 & 68 & 1203,8 & 7854,3 & 0,002625 & 29 & 3 \\
\hline 26 & 1414,5 & 7757,9 & 0,0006 & 6 & 2 & 69 & 1204,0 & 7854,0 & 0,0048 & 73 & 3 \\
\hline 27 & 1414,9 & 7757,6 & 0,007918 & 12 & 3 & 70 & 1203,7 & 7853,9 & 0,0014 & 69 & 2 \\
\hline 29 & 1347,5 & 7805,0 & 0,0009 & 42 & 2 & 71 & 1204,7 & 7854,2 & 0,00016 & 38 & 2 \\
\hline 30 & 1347,6 & 7804,9 & 0,0004 & 16 & 2 & 72 & 1151,8 & 7855,0 & 0,0296 & 56 & 3 \\
\hline 31 & 1348,2 & 7804,9 & 0,0015 & 15 & 3 & 74 & 1156,3 & 7855,5 & 0,01125 & 23 & 3 \\
\hline 32 & 1347,9 & 7805,0 & 0,0021 & 23 & 2 & 75 & 1155,4 & 7855,5 & 0,00025 & 27 & 2 \\
\hline 33 & 1348,8 & 7804,4 & 0,0018 & 73 & 2 & 76 & 1157,2 & 7855,2 & 0,000015 & 77 & 1 \\
\hline 34 & 1348,5 & 7804,1 & 0,007 & 41 & 3 & 77 & 1157,7 & 7855,1 & 0,000036 & 18 & 1 \\
\hline 36 & 1347,0 & 7804,0 & 4,6 & 11 & 3 & 78 & 1158,5 & 7854,9 & 0,00005 & 19 & 1 \\
\hline 37 & 1347,7 & 7804,2 & 0,016872 & 27 & 3 & 81 & 1148,0 & 7856,1 & 0,002 & 60 & 2 \\
\hline 38 & 1347,9 & 7804,3 & 0,016 & 28 & 3 & 82 & 1149,0 & 7856,1 & 0,0015 & 54 & 2 \\
\hline 39 & 1347,9 & 7804,5 & 0,0035 & 30 & 3 & 84 & 1415,6 & 7757,4 & 0,00004 & 37 & 1 \\
\hline 40 & 1348,0 & 7804,5 & 0,0003 & 34 & 2 & 85 & 1415,6 & 7757,4 & 0,000096 & 37 & 1 \\
\hline 41 & 1347,1 & 7804,4 & 0,0035 & 34 & 3 & 86 & 1415,8 & 7757,3 & 0,0026 & 34 & 3 \\
\hline 42 & 1413,0 & 7804,2 & 0,0009 & 92 & 2 & 87 & 1416,0 & 7757,2 & 0,00008 & 47 & 1 \\
\hline 43 & 1411,6 & 7805,7 & 0,0004 & 51 & 2 & 88 & 1416,9 & 7757,3 & 1,3299 & 12 & 3 \\
\hline 45 & 1404,7 & 7816,8 & 0,15768 & 15 & 2 & 89 & 1416,9 & 7757,2 & 0,000006 & 27 & 1 \\
\hline 46 & 1405,5 & 7816,8 & 0,045 & 16 & 2 & 90 & 1415,6 & 7757,0 & 0,000024 & 52 & 1 \\
\hline 47 & 1407,0 & 7817,0 & 0,0192 & 15 & 2 & 91 & 1415,6 & 7756,4 & 0,01113 & 35 & 3 \\
\hline 48 & 1406,9 & 7816,9 & 0,0005 & 21 & 2 & 92 & 1415,0 & 7756,6 & 0,0001 & 61 & 2 \\
\hline 49 & 1611,0 & 7839,4 & 0,0345 & 110 & 3 & 93 & 1415,6 & 7757,8 & 0,00004 & 26 & 1 \\
\hline 50 & 1611,4 & 7839,3 & 0,0377 & 61 & 3 & 98 & 1410,3 & 7800,1 & 0,00035 & 34 & 2 \\
\hline 51 & 1612,5 & 7839,3 & 0,0003 & 50 & 2 & & & & & & \\
\hline
\end{tabular}


845 Appendix 2 Occurrence of invertebrate taxa along the water body age gradient-

Taxa

Age class 1 Age class 2 Age class 3

Age class 4

\begin{tabular}{|c|c|c|c|}
\hline Nematoda & Nematoda & $\mathrm{X}$ & $\mathrm{X}$ \\
\hline Tardigrada & Tardigrada & $\mathrm{X}$ & $\mathrm{X}$ \\
\hline Oligochaeta & Enchytraeus sp. & & \\
\hline Oligochaeta & Lumbricillus sp. & & $\mathrm{X}$ \\
\hline Oligochaeta & Marionina sp. & & \\
\hline Cladocera & Acroperus harpae & & \\
\hline Cladocera & Alona guttata & & \\
\hline Cladocera & Alona werestschagini & & \\
\hline Cladocera & Bosmina longispina & & \\
\hline Cladocera & Chydorus sphaericus & & \\
\hline Cladocera & Daphnia cf. pulex & & \\
\hline Cladocera & Macrothrix hirsuticornis & & \\
\hline Cladocera & Polyphemus pediculus & & \\
\hline Ostracoda & Ostracoda & & \\
\hline Calanoida & Eurytemora raboti & & \\
\hline Calanoida & Diaptomidae sp. & & \\
\hline Cyclopoida & Diacyclops crassicaudis & & \\
\hline Cyclopoida & Cyclops abyssorum & & $\mathrm{X}$ \\
\hline Cyclopoida & Diacyclops abyssicola & & \\
\hline Cyclopoida & Eucyclops sp. & & \\
\hline Harpacticoida & Epactophanes richardi & & \\
\hline Harpacticoida & Maraenobiotus brucei & & \\
\hline Harpacticoida & Tahidius discipes & & \\
\hline Harpacticoida & Nitokra spinipes & & \\
\hline Harpacticoida & Geeopsis incisipes & & \\
\hline Harpacticoida & Nannopus didelphis & & \\
\hline Notostraca & Lepidurus arcticus & & \\
\hline Acari & Ameronothrus lineatus & & \\
\hline Acari & Thalassarachna sp. & & \\
\hline Acari & Halacarellus sp. & & \\
\hline Acari & Camisia foveolata & & \\
\hline Trichoptera & Apatania zonella & & \\
\hline Chironomidae & Diamesa aberrata & & $\mathrm{X}$ \\
\hline Chironomidae & Diamesa bertrami & & \\
\hline Chironomidae & Diamesa gr arctica & & $\mathrm{X}$ \\
\hline Chironomidae & Paraphaenocladius & & \\
\hline Chironomidae & Smittia sp. & & \\
\hline Chironomidae & Cricotopus (s. str.) tibialis & & \\
\hline Chironomidae & Cricotopus s.str. & & \\
\hline Chironomidae & Cricotopus (Isocladius) & & \\
\hline Chironomidae & Psectrocladius barbimanus & & \\
\hline Chironomidae & Metriocnemis gr fuscipes 32 & & \\
\hline
\end{tabular}

$\mathrm{X} \quad \mathrm{X}$

$\mathrm{X} \quad \mathrm{X}$

$\mathrm{X} \quad \mathrm{X}$

$\mathrm{X} \quad \mathrm{X}$

$\mathrm{X} \quad \mathrm{X}$

$\mathrm{X} \quad \mathrm{X}$

$\mathrm{X}$

$\mathrm{X} \quad \mathrm{X}$

$\mathrm{X} \quad \mathrm{X}$

$\mathrm{X} \quad \mathrm{X}$


Age class 1 Age class 2 Age class 3 Age class 4

\begin{tabular}{|c|c|c|c|c|}
\hline Chironomidae & Oliveridia tricornis & $\mathrm{X}$ & & \\
\hline Chironomidae & Hydrobaenus conformis & $\mathrm{X}$ & $\mathrm{X}$ & $\mathrm{X}$ \\
\hline Chironomidae & Paraphaenocladius & $\mathrm{X}$ & & \\
\hline Chironomidae & Orthocladius s.str. & & $\mathrm{X}$ & $\mathrm{X}$ \\
\hline Chironomidae & Chaetocladius s.str. & & $\mathrm{X}$ & \\
\hline Chironomidae & Procladius crassinervis & & $\mathrm{X}$ & $\mathrm{X}$ \\
\hline Chironomidae & Paratanytarsus austriacus & & $\mathrm{X}$ & $\mathrm{X}$ \\
\hline Chironomidae & Micropsectra insignilobus & & $\mathrm{X}$ & $\mathrm{X}$ \\
\hline Chironomidae & $\begin{array}{l}\text { Micropsectra radialis } \\
\text { Goetghebuer }\end{array}$ & & $\mathrm{X}$ & $\mathrm{X}$ \\
\hline Chironomidae & Micropsectra sp. & & & $\mathrm{X}$ \\
\hline Chironomidae & Chironomus sp. & & & $\mathrm{X}$ \\
\hline
\end{tabular}

